\title{
From Javanese Court to African Grave: How Noriman Became Tuan Skapie, 1717-1806
}

\author{
Michael Laffan
}

To cite this article: Laffan, Michael. "From Javanese Court to African Grave: How Noriman Became Tuan Skapie, 1717-1806." Journal of Indian Ocean World Studies, 1 (2017), pp. 38-59.

More information about the Journal of Indian Ocean World Studies can be found at: jiows.mcgill.ca

(C) Michael Laffan. This is an Open Access article distributed under the terms of the Creative Commons License CC BY NC SA, which permits users to share, use, and remix the material provide they give proper attribution, the use is non-commercial, and any remixes/transformations of the work are shared under the same license as the original. 


\title{
From Javanese Court to African Grave: How Noriman Became Tuan SKapie, 1717-1806
}

\author{
Michael Laffan \\ Princeton University, New Jersey
}

\begin{abstract}
This article assembles clues related to the life and impact of an eighteenth century exile to Cape Town known as Oupa or Tuan Skapie (Grandpa/Lord Sheepy). Remembered as a slave sent from Java in the 1770s who tended herds and dug wells on the slopes of Signal Hill in between periods of meditation, it would appear that this subaltern might well have been more than that. Certainly he was successful at concealing his identity (and abilities) from his former jailers and two colonial regimes, finally taking his resting place high on the ridge above Cape Town in 1806, above the space assigned to a more scripturally-charged rival.
\end{abstract}

\section{From Vice to Virtue}

A short walk up past the brightly-coloured homes of Cape Town's "Malay" suburb of BoKaap, perched on the steep sides of the Lion's Rump (Signal Hill), brings one to a recently renovated grave yard. Here, beyond an elegant white gatehouse, lie dozens of graves marked by slates inscribed in Arabic-script Malay. These are dominated by two curious structures rebuilt in the 1970s and dedicated to the local saints Sayyid Alawi and "Tuan Guru" (Abdullah bin Abd al-Salam). The first was an Arab exiled from Java in 1744, while the second was a Tidorese noble sent from the even more distant Moluccas in $1780 .{ }^{1}$ Both endured many years on windswept Robben Island, where the most threatening of Dutch East India Company (VOC) prisoners would languish unless, by the mixed fortune of

1. On Alawi, see Michael Laffan, "The Sayyid in the Slippers: An Indian Ocean Itinerary and Visions of Arab Sainthood, 1737-1929," Archipel 86 (2013): 191-227. For an introduction to Tuan Guru, see Yusuf Da Costa and Achmat Davids, Pages from Cape Muslim History (Gatesville: Naqshbandi-Muhammadi South Africa, 2005), 47-56; and Nigel Worden, Elizabeth van Heynigen, and Vivian Bickford-Smith, eds., Cape Town: The Making of a City; An Illustrated Social History (Capetown: Uitgeverij Verloren/ David Philip, 1998), 124-25. 
poor record-keeping, elapsed time, or even European appearance, they might be brought to the mainland as low-ranking muscle or whisked away by passing ships in need of crew. While Alawi and Abdullah shared the experience of exile and subsequent fame in the Muslim community - a commonality once celebrated in the style of the white-washed walls that enclosed their graves - they probably never met. Either way, the authority they had wielded after their release to the mainland saw them joined not in the old pauper yard down near the beaches at Green Point, but here on Signal Hill, with its scattering of Chinese barrel vaults that commemorated another set of people sent across the waves by Dutch imperial power.

These men are but two of three early figures who lie in the earth of the Tana Baru (New Earth) cemetery - so-called because it was new in relation to the older yard of Green Point. A third saint lies further up the slope, thick with inscribed Robben Island slates and long grass. There, at the apex of a cemetery closed in 1886, and just below homes built in the twentieth century, is a simple edifice dating back to the early 1800 s. Unwalled, yet obscured behind several slates, and wrapped in layers of silk-printed prayers and furtive charms, is the resting place of a man now known as Tuan or Oupa Skapie (Lord or Grandpa Sheepy), who died in the Old Slave Lodge in central Cape Town around 1806, when the British gained final control over the old Dutch colony.

According to the English colonist and diarist Samuel Hudson (1764-1828), who remarked on Tuan Skapie's passing soon after the event, this "very extraordinary character":

had been through the early part of his life guilty of every crime that could disgrace human nature. In the latter part of his time he took an oath to spend the remainder of his existence in penance for his former wicked crimes and gained so much upon the people of his tribe of cast that he was appointed their priest, their doctor, their necromancer, in short, [he] was considered their oracle upon all occasions. His vow bound him to work at some public place from sunrise to sunset which he strictly performed. His chief employment was in sinking deep pits between Cape Town and Green Point for collecting the rain water for the cattle that usually are turned out upon the flats. These places he planted with Aloes and cut channels from the deep ravine in the sides of the Lion's Rump that whenever rains came a considerable portion found its way into these reservoirs. The roads where bad he repaired and it was frequently the case that others by his admonitions were brought to a sense of their misconduct and he enjoyned them in a short penance to assist him for a certain time in his labours. He was then a spare figure of about eighty[,] was wrapped up in an old English great coat and had a kind of calabash covering his head to screen him from the heat of the sun, a girdle round his waist and walked with a long bamboo. His bearing, his figure was so interesting but nothing of that veneration struck you at first 
appearance 'till the character of the man was known. Then you beheld him with that attention a person reclaimed from vice to virtue will ever inspire. ${ }^{2}$

Evidently, the ancient and ultimately virtuous "necromancer" had cut a figure of note in the town. Certainly his great coat and calabash would have marked him out to foreign eyes who normally saw Muslims at work as convicts on the road, or engaged in masonry and draymanship. Indeed, an officer present after the first British capture of Cape Town in 1795 described Tuan Skapie leading just such a crew of road workers. As this anonymous officer had it, he had met with:

a Malay priest, on whose face the wrinkles of age had long taken possession. He was employed superintending a few of his tribe, who were busily engaged in carrying gravel in a basket, which they threw down upon the road, and thus helped to keep it in repair; I understood that such employment is enjoined by them by way of penance for their sins. They seem to be the only class of slaves that interest themselves with the performance of religious duties. To their priests [sic] they pay great reverence and respect, are implicitly obedient to his commands, and from their contributions he subsists. While I remained with the good old father I had an opportunity of seeing he was equally skillful in the art of curing diseases of the body, as well as the soul. A young woman, neatly dressed, with her long hair closely plaited up behind, presented herself before him, and giving him to understand that she was indisposed, asked his advice. With the greatest composure he took a small box from his sack, and striking into its contents a few sparks from the steel, it immediately caught fire, and emitted a somewhat fragrant vapor, with which he bedewed the forehead and temples of the fair supplicant. It had an instantaneous effect, for she took leave with a look of gratitude and apparent relief from her pain. ${ }^{3}$

In the twilight of a long life spent far from his place of birth, Tuan Skapie had risen from penal servitude to become the informal mentor to a subaltern class drawn from across the Indian Ocean, largely from the islands that now make up Indonesia and, to a lesser extent, the East African coast. Indeed, from its founding as a VOC station in the midseventeenth century, Cape Town was the dreaded destination for thousands of slaves, together with hundreds of political exiles dispatched by their home courts, or yet servants

2. Samuel Eusebius Hudson, "Essay on Slaves" (Western Cape Provincial Archives and Records Service [hereafter KAB] ACC 602), as reproduced in R.H. Shell, ed., From Diaspora to Diorama: The Old Slave Lodge in Cape Town (Cape Town: Ancestry24, 2005), CD ROM.

3. Gleanings in Africa: Exhibiting a Faithful and Correct View of the Manners and Customs of the Inhabitants of the Cape of Good Hope (London: Albion Press, 1806), 246-47. 
dumped by homeward-bound officials.

Yet who was this necromancer? And why was he sent to Cape Town in the first place? In some recent publications, such as a local guide produced by the Cape Mazaar Society, he is classified as a slave from the Indies who rose to the rank of "priest" after his arrival in 1770 or $1779 .{ }^{4}$ Yet an examination of the convict lists for Cape Town reveals that this man, who was more often known as Noriman or Norman (both variants of Nur Iman), had been more than an average slave. He first appears in the record in late 1774, when it is noted that on June 7,1773 he (as Norman) had been convicted at a court in Batavia and given a life sentence. Beyond this he is explicitly described as a "Mahomedan priest from Cheribon." ${ }^{\text {A }}$ study of later lists moreover shows that he had been sent (or at least sentenced) together with three of his children, a daughter named Nogie and two sons, Kasan and Koeroe. ${ }^{6}$ Given the very fact of his exile, then, rather than local imprisonment or execution, Noriman, as he shall henceforth be named in this article, had clearly been regarded as an important and dangerous figure, important enough even to have been allowed to travel with his children, like another famous "priest," Shaykh Yusuf of Makassar (d.1699) who had been sent to the Cape a century beforehand.

4. See Mansoor Jaffer, ed., Guide to the Kramats of the Western Cape, 3rd rev. ed. (Cape Town: Cape Mazaar [Kramat] Society, 2010), 44-45; and "South African History Online", accessed September 8, 2015, http://www.sahistory.org.za/archive/1700-1799.

5. KAB, CJ 3189, 150, Lijst van ten Robben Eijland Gecondemeerde Persoonen, 1758-1802.

6. See, for example, KAB, CJ 2568, 160-68, Lyste van soodaanige banditen als er uijt India na herwaards syn gesonden; geformeerd in' $\mathrm{t}$ begin der jaare 1784. I should note here that they are not all marked initially as having been sent together. It is only in 1778 that Nogie is recorded as having been sentenced on June 7, 1773. See KAB, CJ 2568, 62-71, Leijst der Indiaansche bannelingen, die hun alhier aan Cabo de Goede Hoop bevinden en voor hoe langen tijd, zy gebannen zyn, April 10, 1778. 


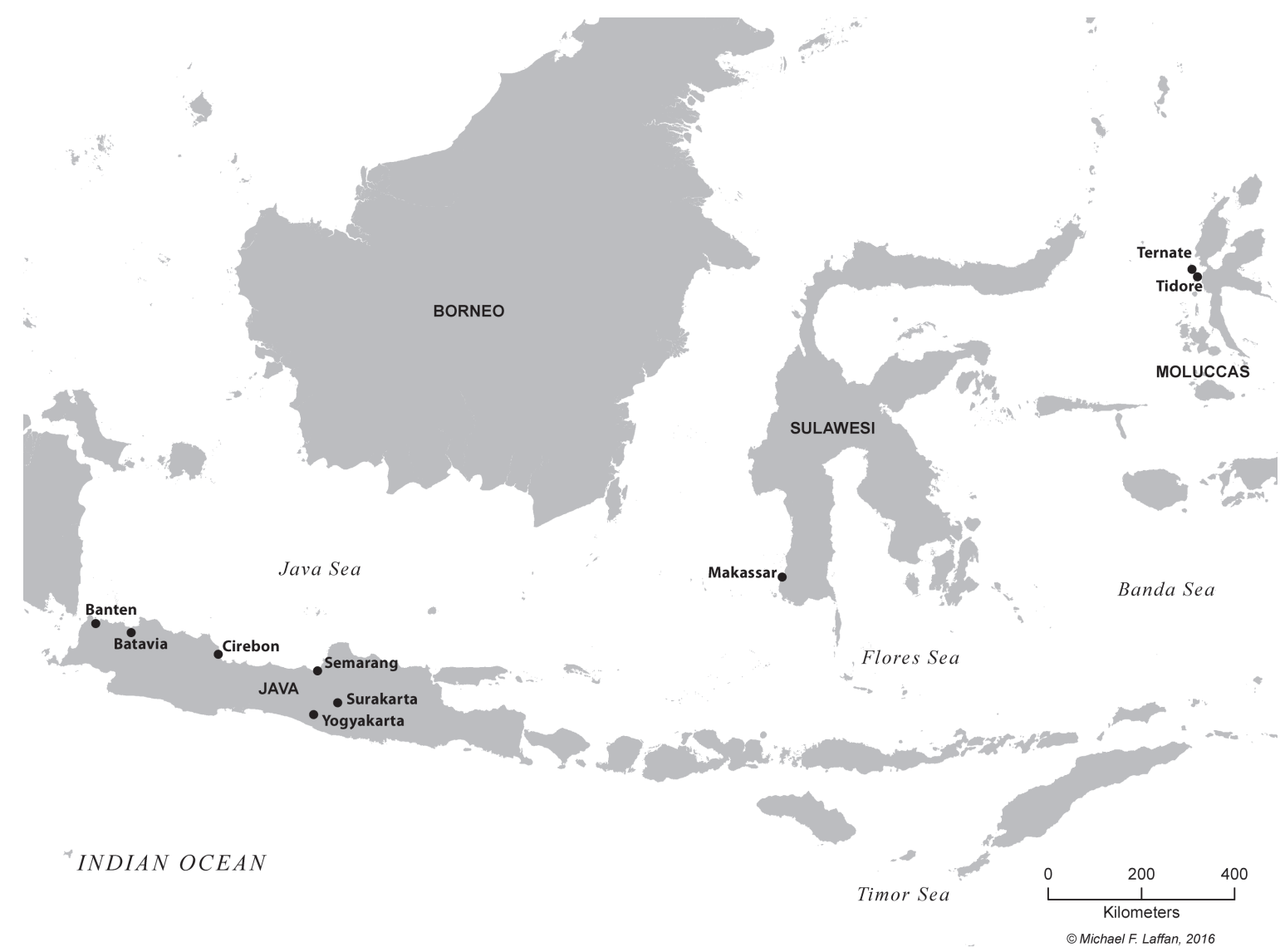

Fig.1 Map of Central Indonesia from South Sumatra to the Moluccas.

Even so, we are left with a when, but we have no why, as there do not seem to be any documents in the Hague explaining the reason for the expulsion of Norman and family from Cirebon, the Javanese port town long famous for the tomb of its sixteenth century founder-saint, Sunan Gunung Jati. Still it would appear that major events were unfolding at a court undergoing a process of final fracture in the shadow of nearby Batavia. Noriman and his kin were not the only elite Cirebonese to be sentenced to life at the Cape at this time, apparently at the behest of the local authorities. For instance, we have reports of the exiling of brigands led in 1772 by one Jaijka (Yahya?) of Cirebon, who had already been implicated in a plot in 1767 under the high-sounding name of Pangerang Mas. ${ }^{7}$ Then we have the enigmatic, and again, seemingly regal, Ingabeij of Cirebon, who was sentenced two weeks after Noriman on July 19, 1773, and who appeared on Robben Island a few months later. ${ }^{8}$ Lastly, there was a party of six men sentenced to exile by the Council of the Indies on April 28, 1774, and who were sent over to Batavia's prison island of Edam on the

7. Indonesian National Archives (hereafter ArNas), Realia, February 23, 1773. In Cirebon, for example, Pangeran Mas was the title taken by Sunan Gunung Jati's successor and founder of the Keraton Kasepuhan in the $1520 \mathrm{~s}$.

8. KAB, CJ 2568, 62-71. Ngabe is Javanese for "boss" or a leading figure at court. 
yacht (pantjalling) ${ }^{9}$ of the "Wendela of Cheribon" (i.e. the Wedana of Cirebon). ${ }^{10}$

The brigand Jaijka, who on February 23, 1773 was sentenced to an impossible 50 years at the Cape, does not appear to have survived his passage, if he was ever sent, while when they had the chance in open waters beyond the Sunda Straits, three of the party dispatched by the Wedana (Koeban, Soekra, and Sikina) threw themselves overboard and were presumed drowned. ${ }^{11}$ In the Javanese imagination, death would not have seemed much worse a fate than exile to the Cape.

Yet, all of these hints of regal tensions remain just that. The literature on the political affairs of Cirebon during this time is opaque, reflecting the fact that very few documents compiled at that post seem to have ended up at the National Archives in the Hague. ${ }^{12}$ We can only speculate for now that there was some internal crisis in one of the town's three courts, perhaps involving our "priest" who would be handed over to the Dutch. I am even tempted to adduce a much-edited eighteenth century text as having some connection to this crisis. This text shows evidence of an attempt to efface images of the awls used in the dabus Sufi ritual, whereby ecstatic supplicants stabbed themselves repeatedly to the beat of drums in quest of visions of the Divine, and in ways that would become regularly practiced in Cape Town in the nineteenth century. ${ }^{13}$ Still I can only confess to treading

9. According to a later guide to Indies vessels found in the collection of the former Minister of Colonies, J.C. Baud (1789-1859), a pancallang was a nimble and lightly-armed vessel of about 40 feet that operated across the north coast of Java with a crew of seven or eight. Such vessels were typically owned by the most senior Javanese official of a given port. See Nationaal Archief, Den Haag (hereafter NL-HaNA), Collectie 058 J.C. Baud, nummer toegang 2.21.007.58, inventarisnummer 1033, Korte Beschrijving van eenige Inlandsche vaartuigen op Java in gebruik zijn.

10. KAB, CJ 2568, 2, Extract uit de notulen van het geresolveerde in Raade van Indië op den 28 April 1774. This group included Koeban and Kedisam of Astana (i.e. the palace), and Vaisam, Kalidem, Soekra, and Jikina (or Sikina) of the neighboring town of Gabang. The first three were sentenced to three years labour in chains, and the rest were sentenced for life. A Javanese woman, Jamie of Casepoean (Kasepuan - another of Cirebon's courts), was excused from exile, but nonetheless condemned to life in chains on Edam.

11. Koeban, Soekra and Sikina apparently jumped into the Indian Ocean on the night of November 6, 1774, having been released from their irons to assist with the ship. KAB, CJ 2568, 7, Statement of Evert Wessling, Jan Bockx, and Docus Faantjes, aboard the Mars, November 8, 1774.

12. In any case it would appear that the challenge of the Balinese in East Java was of more pressing concern to Batavia. See Sri Margana, "Java's Last Frontier: The Struggle for Hegemony of Blambangan, c. 1763-1813," (PhD Diss., Universiteit Leiden, 2007).

13. Perpustakaan Nasional Indonesia (Indonesian National Library), ms A70, Kitab Mawlid. For an unblemished page from this same text, see James Bennett, Crescent Moon: Islamic Art \& Civilisation in Southeast Asia, (Adelaide and Canberra: Art Gallery of South Australia and National Gallery of Australia, 2005), 168. On the dabus/ratiep, see Jacob Vredenbregt, "Dabus in West Java," Bijdragen tot de Taal-, Land- en Volkenkunde 129 (1973): 302-20; Margaret J. Kartomi, "Dabuih in West Sumatra: A Synthesis of Muslim and Pre-Muslim Ceremony and Musical Style," Archipel 41 (1991): 33-52; and Desmond Desai, "The Ratiep Art Form of South African Muslims," (PhD Diss., University of Natal, 
speculative water in this regard, much as I have previously suggested that Sayyid Alawi could have been made an unofficial patron of such acts of stabbing and burning when the old quarry became their staging ground at the end of the eighteenth century. ${ }^{14}$

Condemned, after a long and agonizing voyage below deck, to the boredom of Robben Island where prisoners worked quarrying stone (much as Nelson Mandela would), or hunted penguins to supplement their impoverished diet, ${ }^{15}$ Noriman and his children would see six years pass before the arrival of the next Indonesian to be identified as a religious figure. ${ }^{16}$ This was the future "Tuan Guru", Imam Abdullah, who was a member of a party of four Tidorese nobles charged with treating with the English in the Moluccas. ${ }^{17}$ Confusingly, in the convict lists, one of these four, who were all landed on Robben Island in mid-April 1780, was the similarly named Noeroiman (another variant of Nur Iman). Still, he would have been distinct from our Noriman, who since 1778 had also begun to be designated as having been from Batavia - doubtless a slip of the pen based on his place of sentencing, but one set to be repeated in years ahead. ${ }^{18}$

In any case, the two men were not together long in 1780, as hostile English sails were looming on many a Dutch horizon with the outbreak of the fourth Anglo-Dutch War (1780-1784). The Dutch would soon lose their Indian bases and manpower, though not their prize possession in Africa. When Commodore George Johnstone arrived off Cape Town in July 1781, he found a port recently reinforced by a French fleet that had surprised him in the Cape Verde Islands two months earlier, and he had to content himself with a raid on several merchant ships at anchor further north in Saldanha Bay on July 21, 1781.

Given Robben Island's exposure to passing ships, the convicts - European and Asian - had already been removed to the mainland by early February of that year, mostly assigned to public works, and housed at the slave lodge in central Cape Town. ${ }^{19}$ It would also seem that Noriman and the royal Tidorese parted company at this moment, with the latter being given greater freedom in the town. Two of the Tidorese - their leader Qadi

1993).

14. Laffan, "At Sea with Sayyid Alawi," 220-25.

15. Perhaps the best summary of the island and its operations under the Dutch is Nigel Penn, "Robben Island 1488-1805" in The Island: A History of Robben Island, 1488-1990, ed. Harriet Deacon, (Cape Town \& Johannesburg: David Philip, 1996), 9-32.

16. In another case in 1778 a Ternaten "prince," Minte, was erroneously described as a priest. See KAB, CJ 2568, 141-147.

17. Unfortunately their precise activities and the charges are not discussed by Widjojo, who paints a picture of the events surrounding efforts made by Sultan Jamal al-Din to encourage a British alliance in 1779. See Muridan Widjojo, The Revolt of Prince Nuku: Cross-Cultural Alliance Making in Maluku, c.1780-1810 (Leiden: Brill, 2008), 168-71.

18. KAB, CJ 3189, 184 \& 204, Lijst van ten Robben Eijland Gecondemeerde Persoonen, 1758-1802.

19. KAB, CJ 2568, 122-24. 
Abd al-Rauf and Noeroiman - even managed to get to one of the English ships that took them on to Madras. ${ }^{20}$

We are in no position to know what Noriman and his family (or the subsequently lodge-bound Tidorese Abdallah and Badr al-Din) felt about their companions' relative fortune. It seems that the authorities were in no hurry to return them to Robben Island. In the case of Noriman and his elder son Koeroe, this initiated a long period of labour at various sites. For Noriman, this ranged from clearing reeds in the appropriately named Rietvlei ("Reed Valley"), to the north, in April 1782, to works in and around the town itself, particularly in the Company Gardens, which had long been a famous site for the propagation and export of African varietals. ${ }^{21}$ Koeroe seems to have been given similar jobs while Kasan, as a criminal minor or "bandietjongen," was given lighter tasks. ${ }^{22}$

It is not clear what became of Noriman's daughter, Nogie. The last mention of her appears in a list from 1784, though this list was merely a cumulative summary of all the exiles sent since 1722. There is a strong likelihood that Nogie died on the mainland soon after her arrival, if she was indeed sent in the first place - Robben Island was a decidedly male destination after all. ${ }^{23}$ Nonetheless, it is interesting how this later list, which gives convict names ordered by their date of sentencing, reminds us once more that Noriman arrived at a peak moment for exiles of rank from not just Cirebon, but also the related West Javanese court of Banten. If the use of Javanese honorific titles is anything to go by, it includes mention of two royal Bantenese - Ratoe Bagoes Oedip and his son Ratoe Bagoes Nassar (both sentenced in May 1773) - and the equally regal Cirebonese, Ingabij Cheribon and (his son?) Ingabij Dota Laxama, sentenced in July $1773 .{ }^{24}$

20. British Library, India Office Records and Private Papers (hereafter IOR), L/PS/19/14, p. 4 note, Memoir [of Alexander Dalrymple] concerning Kecheel Nookoo Sultan of Teedoré, February 11, 1801. As lodge notes from 1782 record, while Noriman was at the "Riet Vallij" and the remaining Tidorese in the lodge, "Caali ap dul Rouff" and "Noeroiman" were "bij de Engelsen overgegaan." KAB, CJ 3189, 228-23, Rapport van de Gecondemeerdens van t' Robben Eijland op 1den April 1782.

21. KAB, CJ 3189, 230, 245, Lijst van ten Robben Eijland Gecondemeerde Persoonen, 1758-1802.

22. KAB, CJ 2568, 176-178, Notitie van sodaanige Chineesen en bandieten als er alhier bij de generaale monsterrolle in s' Comp:s Slavenlogie bekent staan en voor soo verre het den ondergeeteekende weet als nog op heiden in weesen zijn, February 21, 1786.

23. KAB, CJ 2568, 160-68, Lyste van soodaanige banditen als er uijt India na herwaards syn gesonden Geformeerd in 't begin der jaare 1784. It is likely that Nogie had been excused the fate of exile by virtue of her sex much as Jamie of Casapoean would be. See no. 10 above.

24. KAB, CJ 2568, 160-68. Other documents note the arrival of the Bantenese father and son on January 19, 1774. See KAB, CJ 3189, 141, Lijst van ten Robben Eijland Gecondemeerde Persoonen, 17581802. 


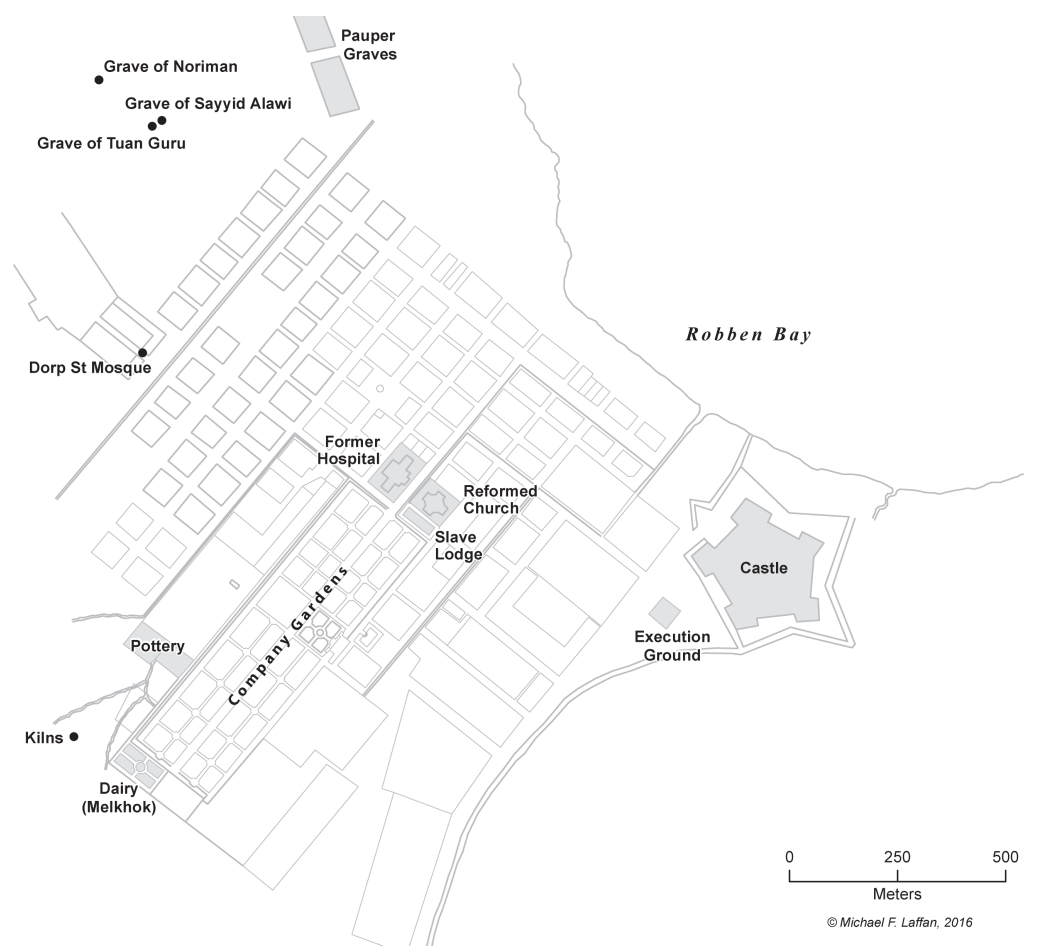

Fig.2 Map of Central Cape Town, c. 1785-1806. Based on NL-HaNA, 4-TOPO 15.84.

Those exiles still alive were on the mainland at this time, and as of February 21, 1786, the lists show that Noriman was engaged working in the dairy on the edge of the Company Gardens (and effectively the edge of the town) known as the Melkhok. ${ }^{25}$ This was likely where he first developed his reputed solicitude for cattle, remarked upon by Samuel Hudson, much as work in the Gardens may have accustomed him to his future interest in planting aloes. Given that only one or two slaves were ever stationed in the Melkhok, it may have been a relatively privileged sinecure when compared with the lodge, which was infamous for its crowding. It also appears that his sons, who were indeed housed at that undesirable address, were still on Company business. The older of the two, Koeroe, was placed in the Gardens, while Kasan and the younger of the Cirebonese Ingabijs mentioned above were listed as convict youths in government service. ${ }^{26}$

In short, the threat of British invasion saw Noriman (once "of Cirebon" and now occasionally "of Batavia") gain the opportunity in Cape Town to merge with a far larger community drawn from across the old VOC domains from the Cape to the far Moluccas. It furthermore gave him a new lease on life and some income as informal minister to his

25. KAB, CJ 2568, 176-78, Notitie van sodaanige Chineesen en bandieten als er alhier bij de generaale monsterrolle in s' Comp:s Slavenlogie bekent staan en voor soo verre het den ondergeeteekende weet als nog op heiden in weesen zijn, February 21, 1786. A map from 1785, which is the basis for Fig. 2, shows the "Melkboer" at the end of the gardens between a zoo and pottery, with evidence of humble accommodation on the banks of a stream. See Nationaal Archief Collectie C.J. van de Graaff, 4-TOPO 15.84. This section of the gardens now lies within the grounds of the South African Museum and Planetarium. With thanks to Nigel Worden.

26. KAB, CJ 2568, 176-78. 
fellow believers, whose ranks grew as others came to identify with Islam as a subaltern identity. While the practice of Islam was technically forbidden in Dutch forts and cities, some rituals were being celebrated in private homes and with the patronage of the elite exiles from Java. ${ }^{27}$ By the same token, it would seem from later hints that the more ecstatic rituals of piercing and drumming were held in the old quarry. ${ }^{28}$ This lay just below Signal Hill's simple Chinese tombs, where Sayyid Alawi had been recently interred, perhaps by virtue of his association with them. Indeed he last appears in the records in 1773, when he testified to the circumstances surrounding the death of his Chinese landlady. ${ }^{29}$

Whether one might link Noriman to Sayyid Alawi, alive or dead, or yet to these forms of ritual is problematic, for he had no say as to where he was posted, and was doubtless detained by night. Even so, from his hut on the edge of the Gardens, he soon attained fame as a provider of healing and protection who was accessible at all hours, as the aftermath of the events of August 6, 1786 soon demonstrated.

\section{Of Runaways and Amulets}

The Dutch of Cape Town were always made nervous by their numerous charges who had an obvious presence on the streets, whether in the employ of the Company or as domestic servants. This included women in the home, and men roaming the hills to collect firewood. A secret East India Company plan, hatched in London in preparation for Commodore Johnstone's foray, opined that, of the slaves, "one half, or two fifths are Malays and much more dreaded by the Dutch in case of an attack, or invasion, than a foreign Enemy." ${ }^{30}$ Even if Capetonian Dutch, then in the process of becoming Afrikaans, was the language of command and social interaction in the settlement, many of the slaves, exiles, and "free

27. Carl Peter Thunberg, Travels at the Cape of Good Hope, 1772-1775 (Van Riebeeck Society: Cape Town, 1986), 47-48; Kerry Ward, Networks of Empire: Forced Migration in the Dutch East India Company. (Cambridge: Cambridge University Press, 2009), 227.

28. Certainly they would become the object of horrified fascination in later years. See A.W. Cole, The Cape and the Kafirs: Or Notes of Five Years' Residence in South Africa. (London: Bentley, 1852), 4446; see also "Islam at the Cape," Cape Monthly Magazine, December 1861, 353-63, esp. 356-60.

29. James C Armstrong, "The Estate of a Chinese Woman in the Mid-Eighteenth Century at the Cape of Good Hope," Journal of Chinese Overseas 4, no. 1 (2008): 111-126. A preparatory sketch by the cleric Jan Brandes in 1786-87 appears to show an early version of Alawi's tomb as foreground to a view of the peak known as the Leeuwenkop. See Rijksmuseum, NG-1985-7-1-43. On the simple tombs of the Chinese that were joined by those of local "free blacks" and which would later take on more imposing forms in the nineteenth century, see Thunberg, Travels, 49; and Andrew Sparrman, A Voyage to the Cape of Good Hope towards the Antarctic Polar Circle and Round the World: But Chiefly into the Country of the Hottentots and Caffres, from the Year 1772, to 1776, 2 vols. (New York and London: Johnson Reprint Corporation, 1971), I, 12.

30. British Library, IOR, L/PS/1/5, 91-92, Minutes of the Secret Committee 1778-1858, May 22, 1780 to February 23, 1782 (note that pagination restarts earlier in the volume). 
blacks" also made use, open and covert, of Malay, Bugis, and even Malagasy as alternate means of communication. ${ }^{31}$

The possibility of violence often loomed in the grog-soaked port as well as on the farmsteads of the hinterland. While many farms depended on the labour of household slaves, their owners preferred not to be outnumbered by them. Far more fearsome, though, were the groups of runaways that took to the hills and lived furtive existences, sometimes in the company of surviving members of the Khoi communities that had once herded their cattle across the landscape.

It was this terrifying scenario that played out in early August 1786, when a typicallyhybrid party of runaways, including August van de Caab, Andries van Calkuta, Jonas van Batavia, Damon van Bougies, Saripa van Mandhaar, and Welkom van Ternate, overran the farmstead of the absent Sebastiaan Rothman, smashing in the doors and killing his retainers and family, infants included, in a grisly fashion. ${ }^{32}$ The attackers had already been able to move around for some months with forged letters of passage, requesting food from other homesteads, and demanding supplies from local Khoi. Following the murders, the runaways were soon apprehended and eventually interrogated in the castle in November, whereupon they were asked to explain two items in their possession: a small lead disc inscribed with "Malay" letters, and an "Arabic" (or "Malay") document that was folded around a mysterious black powder. Under interrogation, Jonas named the source of the former as a "priest" known as Noriman, while his colleague Damon explained its protective powers.

So it was, that on November 13,1786, Noriman found himself in the interrogation room of the castle being questioned by Johannes Martinus Horak in the presence of the clerk R.G.G. Riet. ${ }^{33}$ If the rough third-person reportage of their questions and his evident evasions are anything to go by, no attempt had been made to seek Noriman in the lists of convicts and exiles. Noriman was first asked to give his name, age, and place of birth, to which the clerk recorded that he responded that he was "Norman," about 69 (naa gissing), and born in "Marantau." 34 The last Malay word perhaps best translates as "here and there," and refers to the tradition of out-migration and coasting undertaken by

31. While the use of Malay is certainly discernable from the surviving documents and Islamic manuscripts in use in the nineteenth century, it has only been relatively recently that Pier Larson has pointed to the parallel endurance of Malagasy. See Pier M. Larson, Ocean of Letters: Language and Creolization in an Indian Ocean Diaspora. (Cambridge: Cambridge University Press, 2009), 239.

32. See "1786 Augustus van de Caab et.al.," in Nigel Worden and Gerald Groenewald, eds., Trials of Slavery: Selected Documents Concerning Slaves from the Criminal Records of the Council of Justice at the Cape of Good Hope, 1705-1794, Series 2, no. 36 (Cape Town: Van Riebeeck Society for the Publication of South African Historical Documents, 2005), 537-556.

33. The text of the interrogation is found in KAB, CJ 424, 555-560.

34. KAB, CJ 424, 555. 
many communities in island Southeast Asia. ${ }^{35}$ With Marantau duly noted as his island of origin and that the Melkhok was his current address by men who may well have had Malay as basic as his Dutch, the hard questions began in earnest. In what year was he dispatched from Batavia and why? Did he not admit to having officiated as a priest of the Mohammedan religion since that time? In so doing, did he not admit to carrying out unusual practices, and that he was regarded as a soothsayer? Did people not come to his house on a daily basis to seek his counsel in this regard? ${ }^{36}$

To the first questions he simply remarked that he had been at the Cape for such a long time that he could no longer remember, while all other matters produced straight-forward denials. From here, things went from bad to worse for our wanderer. Given the transcript often omits answers in the appropriate margin and substitutes the word "irrelevant" (vervalt), it is apparent that Horak and Riet were already convinced of his guilt based on their earlier conversations with Jonas and Damon. Such was the case with question seven, which concerned whether Noriman ever gave his visitors anything. The answer, in the eyes of Horak and Riet, was a clear yes. As the third-person notation of Norman's interrogation continues:

8 So what was this thing that he had given them? He said No!

9 And would that preserve him from misfortune, or yet from being traced?

He said that he knew nothing of this.

10 And was he not sure that that these people were gullible enough to adhere to his belief? He said No!

11 And did he not agree that what he had distributed to such [people] was not affirmed as a charm. He said that he knew nothing of it.

12 And did he know the slave Jonas of Batavia, the property of Willem van Reenen and previously of a certain Elias Volberg, commonly known as Bookiman Elias?

He said no. [At which point] Jonas came in and told the prisoner that he had known him on the Island. ${ }^{37}$

Unluckily for Noriman, Jonas of Batavia had indeed been on Robben Island, arriving on February 3, 1777 after being sentenced to temporary displacement for some further

35. Perhaps the most famous of such sojourners are the Minangkabau of West Sumatra, though the concept is familiar across ethnic lines.

36. KAB, CJ 424, 556-557.

37. KAB, CJ 424, 557. 
misdemeanor at the Cape when he was a slave belonging to the Widow Elisa Davids. ${ }^{38}$ Whatever the nature of their relationship, Noriman and Jonas must surely have known each other given that there had only been some 100 "Indians" on the island that year, who were all obliged to sleep in a separate kraal some distance from the more livable barracks of the European prisoners and their overseers. Given his status, and perhaps even his patronage of new arrivals on the island and later in Cape Town, Noriman must have been seen as an obvious source of aid when Jonas and his party absconded. Thus one night they would creep down to his accommodation, lying as it did on the exposed end of the Company Gardens.

From here the interrogation proceeded in a more deliberate arc, concentrating on the small item that Horak and Riet were convinced that Noriman had given Jonas. As the opaque notes record:

13 Did he admit to sometimes having given this slave Jonas something for security and protection from misfortune?

Said No! Jonas then came in and said that he had given him an amulet (lootje) or charm (bezweering). The suspect continued to deny this.

14 Against what misfortune had he given such help? Vervalt.

15 The suspect was shown the amulet and asked did he not recognize it?

Said that he did not recognize it.

16 How is such a thing used?

Said he had no idea of such.

17 Had Jonas not asked for such from him and obtained it during his abscondence?

Said I know nothing of it.

18 And was that amulet not for protection and preservation from detection?

Said again that he knew nothing of it.

19 So can someone with such an amulet be discovered? Vervalt!

20 Did he also believe in the power of this charm? Vervalt.

21 Had he misled us [sic] by giving such [a thing] to someone else and had thus given Jonas assurance of its power?

38. KAB, CJ 3189, 172-174, 178-180, and 192-95. Here the widow is also named at one point as Elisabet Davids. It therefore seems that Elias was a scribal error for Elisa. 


\section{Vervalt.}

22 What was the actual content of the text?

Said I do not know.

23 Were there other people had obtained such amulets and scraps from him or requested the same?

Said no!

24 Were there people other than the prisoners here who carried such charms?

Said I know nothing of that.

25 Did he not understand that in giving such amulets and papers out he had misled many gullible people? Said I know nothing of that. ${ }^{39}$

With that, we hear no more from the direct, or nearly direct, voice of Noriman, as his fellow prisoners sweated nearby.

Writing in summary three days later, Vliet advised the Council of Justice that "a certain exile here" was a "bloodsucker" (zogen). According to the information of Jonas of Batavia, the "Mohammedan priest known as Norman" had given him an amulet with Arabic incantations which, according to the slave Damon, was "equivalent to a spell or absolution granted by a saint that would forever protect them from wild animals or even capture and any adversity during their flight." ${ }^{40}$

As Vliet continued, "no matter how ridiculous" such ways of thinking might be to any Christian, "this sort of superstition generally has no small influence on the great majority of the slaves," leading them not merely to abscond, but also to commit abominable violence. In his view, then:

this so-called priest Norman must be considered culpable as the immediate cause [of the violence] at the very least. Therefore I humbly request that this same Norman, by special order ... shall be put to torture or ... until such time as another means of dealing with him shall be determined, be put on Robben Island. ${ }^{41}$

This "so-called priest" was lucky. The council determined that since Noriman, whom they believed had been banished from Batavia in 1770 for crimes unknown, had not admitted to any connection to the lead amulet (he never signed the transcript), they

39. KAB, CJ 424, 558-60.

40. KAB, CJ 424, 545-552, R.J. van Vliet to Pieter Hacker and Johannes Isaak Rheinen, Raad van Justitie, November 16, 1786.

41. KAB, CJ 424, 552. 
would send him to the island yet again until more evidence came to light, as there was plenty of hearsay and uncertainty involved. It was also noted that the document appeared to contain incense (with which the amulet given to Jonas was perhaps to be periodically renewed by fumigation). ${ }^{42}$

Sundered from Capetonian society once more, Noriman was at least spared the exemplary torture meted out to the companions of Jonas on November 23, 1786. Stripped naked and lashed to crosses, they had the flesh torn from their bodies with hot tongs before being broken alive from the legs up, and without the coup de grâce. Jonas, as chief confessor, was merely killed. ${ }^{43}$

Nor was Noriman the only priest to be so removed. A probably bewildered Abdallah of Tidore was returned to the island at the same time together with a Ternaten "prince", though this is suggestive less of a coordinated plot than general Dutch anxiety, and perhaps indicates that Abdullah had faced the same set of questions, relevant or not, from Horak and Vliet.

Whatever the truth of the matter, Noriman and Abdullah most likely did not share the same approach to scripture if their surviving texts are any indication of their powers of language. On the one hand, it is clear that Abdullah was able to write in Arabic. This is demonstrated by the Quran he is said to have written on the island (possibly during this second, but more likely during his first respite in town), as well as his ability to write in Arabic-script Malay -- as can be seen from his compilation of a collection of jurisprudence that circulated after his return to the mainland in $1791 .{ }^{44}$ On the other hand, Norman's "Arabic" letter used by Damon to enclose the incense is something very different.

To begin with, the script and opening lines of the letter are certainly not Arabic (or even Malay), while the subsequent passages vocalizing that language are barely comprehensible, being a doggerel-like fusion of pious phrases. Indeed, the overriding language of the incriminating letter is Bugis, the tongue of a prominent diaspora of the same name originating from the island of Sulawesi. Moreover, the document would appear to be the leaf of a larger manual, perhaps even one written at a much earlier date, perhaps even in Asia. ${ }^{45}$

42. Worden and Groenewald, Trials of Slavery, 550.

43. Worden and Groenewald, Trials of Slavery, 555.

44. A copy of Abdullah's compilation Ma rifat al-Islam wal-iman (which was already a well-known manual in use in Southeast Asia) is now held by his lineal descendants in Cape Town. According to Saarah Jappie, he describes Cape Town at one point in Arabic as the "place of sadness" (makan al-huzn). 45. I am grateful to Roger Tol for having translated the Bugis and transcribed the Arabic sections of the document. The observations about the age of the text and probable location of writing were made by Dr. Ahmad Rahman of Jakarta. With thanks to Saarah Jappie. 


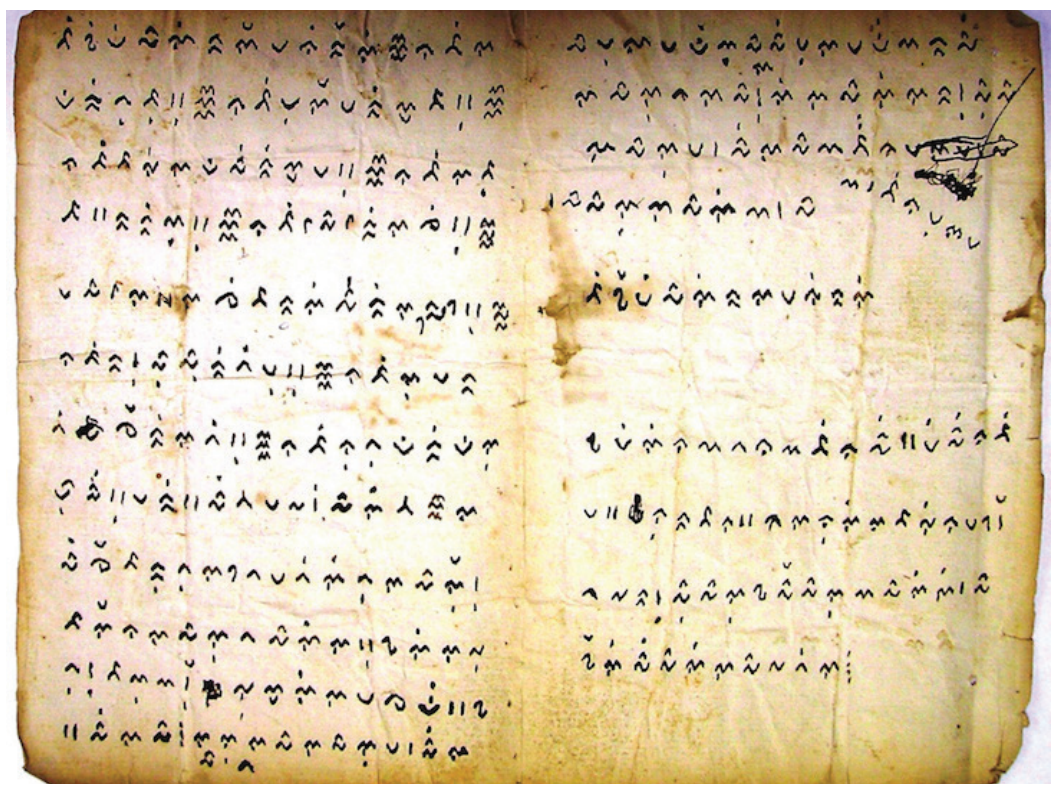

Fig.3 The alleged Arabic document of Noriman. Western Cape Provincial Archives and Records Service (KAB), CJ 424, 703. Permission for reproduction gratefully acknowledged.

This presents us with a problem. Did Noriman really know nothing about the amulet and the letter waved before him in the castle cell? After all, there were others in Cape Town who could write in Bugis, as a 1760 case of some runaways and a hapless correspondent shows. ${ }^{46}$ That said, Noriman's evasiveness and self-declared origin as being of the rantau makes a Bugis origin entirely possible, whether as a recent migrant to Java in search of adherents, or as the descendant of so many other sojourners who had flooded the ports of the Java Sea during the period of Dutch dominance. ${ }^{47}$ In one of the few reports from Cirebon that made its way to the Hague in the late eighteenth century, the Bugis are listed as one of the main minority groups in the port, where many of them were employed by the VOC as soldiers. ${ }^{48}$

What sort of Islam is represented in the text? The Bugis opening is interesting in and of itself, even if it defies ready analysis:

Bismillahi rahmanirrahim. Nabi Adam ri tubukku. Nabi Muhammad ri nyabaku. Nabi BaGiADaLi rinyamakku. Nabi Abu Bakar riwukku. Nabi LéRé ri ajikku. Malaékah Jibrail ri oloku. Nabi rasululu ri timukku. Nabi Umar tijjang ri atikku. Nabi Nuh tudang ri daung culikku maringkalinga mappasilainga.

46. See Sirtjo Koolhof and Robert Ross, "Upas, September and the Bugis at the Cape of Good Hope: The Context of a Slave's Letter," Archipel 70 (2005): 281-308.

47. Leonard Y. Andaya, The Heritage of Arung Palakka: A History of South Sulawesi (Celebes) in the Seventeenth Century (The Hague: Nijhoff, 1981).

48. NL-HaNA, Hoge Regering Batavia, 1.04.17, inv.nr. 1000, 17-20, Memorie van de resident van Cheribon J.L. Umbgrove over zijn residentie, 1792-1797. 
In the name of the Benevolent, the Merciful: Prophet Adam is in my body. Prophet Muhammad is in my soul. Prophet "Baqi Adali" [?] is my beloved. Prophet Abu Bakar is my beacon. Prophet LéRé [Khidr] is on my foot. The Angel Gabriel is before me. The Prophet Messenger of God is in in my mouth. Prophet Umar stands in my heart. Prophet Noah sits on my ear, listening and admonishing. ${ }^{49}$

According to the Javanist Ben Arps, the language of this text is akin to that of old Javanese amulets known, following the Arabic, as azima, which situate holy beings at various points of the body for protection, and in ways similar to those also found in non-Muslim contexts, such as Bali. ${ }^{50}$ Whatever the understood meaning of this text - which situates an assortment of prophets (including Muhammad twice for good measure), an archangel, and a couple of caliphs in the consciousness of the protected believer - it is hardly representative of an orthodox teaching of the difference between prophets and caliphs, or of how they would lend their help to benighted Muslims.

One wonders, too, whether the words of Noriman's text were intended to be restated by their possessors between fumigations, though the mysterious powder it enclosed was more likely intended to absorb the words from their sacral container, which were then to be released into the amulet upon ignition. This ritual was perhaps practiced in order to bestow protection during risky ventures, such as the assault on the farm of Sebastiaan Rothman.

\section{From ISLAND To HiLlside}

Whatever his abilities, it is highly unlikely that Noriman would have been given access to paper once he was returned to Robben Island, where the indifferent record-keeping of the Postholder soon had him listed as a priest from Banten, sent over from the Cape in January 1787. It was this designation that he maintained for the following four years during which time he may well have had a testy relationship with the more scripturally accomplished Imam Abdullah, until the latter was able to return to the town in July 1791, at a time when VOC prohibitions on religion began to ease once more. Within two years, Abdullah was even able to operate a small school from his own home, and an unofficial mosque appeared on Dorp Street by 1794.

49. KAB, CJ 424, 703.

50. Ben Arps, personal communication with author, August 25, 2015. See also Bernard Arps, "The Song Guarding at Night: Grounds for Cogency in a Javanese Incantation," in Towards an Anthropology of Prayer: Javanese Ethnolinguistic Studies / Vers une anthropologie de la prière: études ethnolinguistiques javanaises, ed. Stephen C. Headley (Aix-en-Provence: Publications de l'Université de Provence, 1996), 47-113, esp. 55-56. 
Noriman, by contrast, had to wait until the middle of 1793 to be returned to the Slave Lodge, though he was accorded the rather elevated designation of "Indies Prince." Had he known it, this title may have irked Imam Abdullah who, when preparing his will in 1801, described himself to the registrar as "a former Prince of the domain of Tidore in Ternate" (volgens Zyne betuiging gewesend Prins van't landschap Tedori in Ternaten). ${ }^{51}$ It is doubtful whether Noriman would have been able to pass himself off as such in local Muslim society in the 1790s, though his new tasks with the public works would have brought him in more frequent contact with potential followers in the form of the quarry workers and road crews we met at the opening of this article.

Whatever the case, Noriman's situation seems to have changed little in the wake of the successful British invasion of 1795, when the new authorities were eager to maintain the status quo. Slavery was an enduring reality and Dutch continued as the language of administration, though several of the town's openly Islamic figures, led by Abdullah, were keen to press for rights to prayer spaces, free residence and future interment, with their eyes fixed on the slopes of Signal Hill.

It was during this period, then, that the aged Noriman would have taken his final form as the master confessor and healer. Here was a man not of the mosque, but of the way, who moved among the people with his trusty sack of incense and incantations, and who could be seen clearing the ground in the manner of the Sufi pioneer of Muslim legend, who is said to make a space for future settlement. Doubtless Dutch burgers and British officers alike still saw his incantations as so much hocus pocus, and now they had more established imams like Imam Abdullah to deal with.

Upon their brief return in 1803, the metropolitan Dutch authorities (rather than the old VOC regime) continued to deal with such figures when appealing to local Muslim sentiment, and granted religious freedom in 1804. In July 1805, for instance, the "Javanese priest" Frans van Bengal petitioned the administration of Dutch governor Jan Willem Janssens for formal rights to the burial ground located around the tomb of Sayyid Alawi on Signal Hill, perhaps with an eye to a future resting place for Imam Abdullah, whose mantle he hoped to inherit. ${ }^{52}$

Today local histories, some found online, have it that Janssens was a personal friend to Noriman, who had become a kindly herdsman and sinker of wells. ${ }^{53}$ It is even

51. KAB, MOOC 7/1/53, 66. Included in this file is a copy of the Malay summary text made by Abdullah's follower Frans van Bengal, assigning his worldly goods to two sons, Abd al-Rauf and Abd al-Rakib.

52. The request would be granted in October. See KAB, RDG 2, 132 and 149-150. Evidently such efforts did not gain traction with Tuan Guru's congregation, which would be led by Achmat van Bengal from 1807. Frans would depart with Jan van Boughies and found the rival Palm Tree mosque closer to the Gardens on Long Street. See Da Costa and Davids, Pages from Cape Muslim History, 42; and Worden, Cape Town, 125-27.

53. Jaffer, Guide to the Kramats of the Western Cape, 45; "South African History Online", accessed September 8, 2015, www.sahistory.org.za/archive/1700-1799. 
said that by 1806 he lived not in the old slave lodge but in a small shack well above the enclosure of Alawi where Janssens granted him a burial site. Such stories, though, may just be incorporating a version of the 1805 request of Frans van Bengal, for Noriman's resting place is well above the bounds of the allotment of the Tana Baru. Apparently, it was stipulated that no wall be placed around his grave, further distancing himself from the formalist practices of the scholarly holy men below (alive and dead) and inviting greater visitations from many in the community who preferred his style of religion. ${ }^{54}$

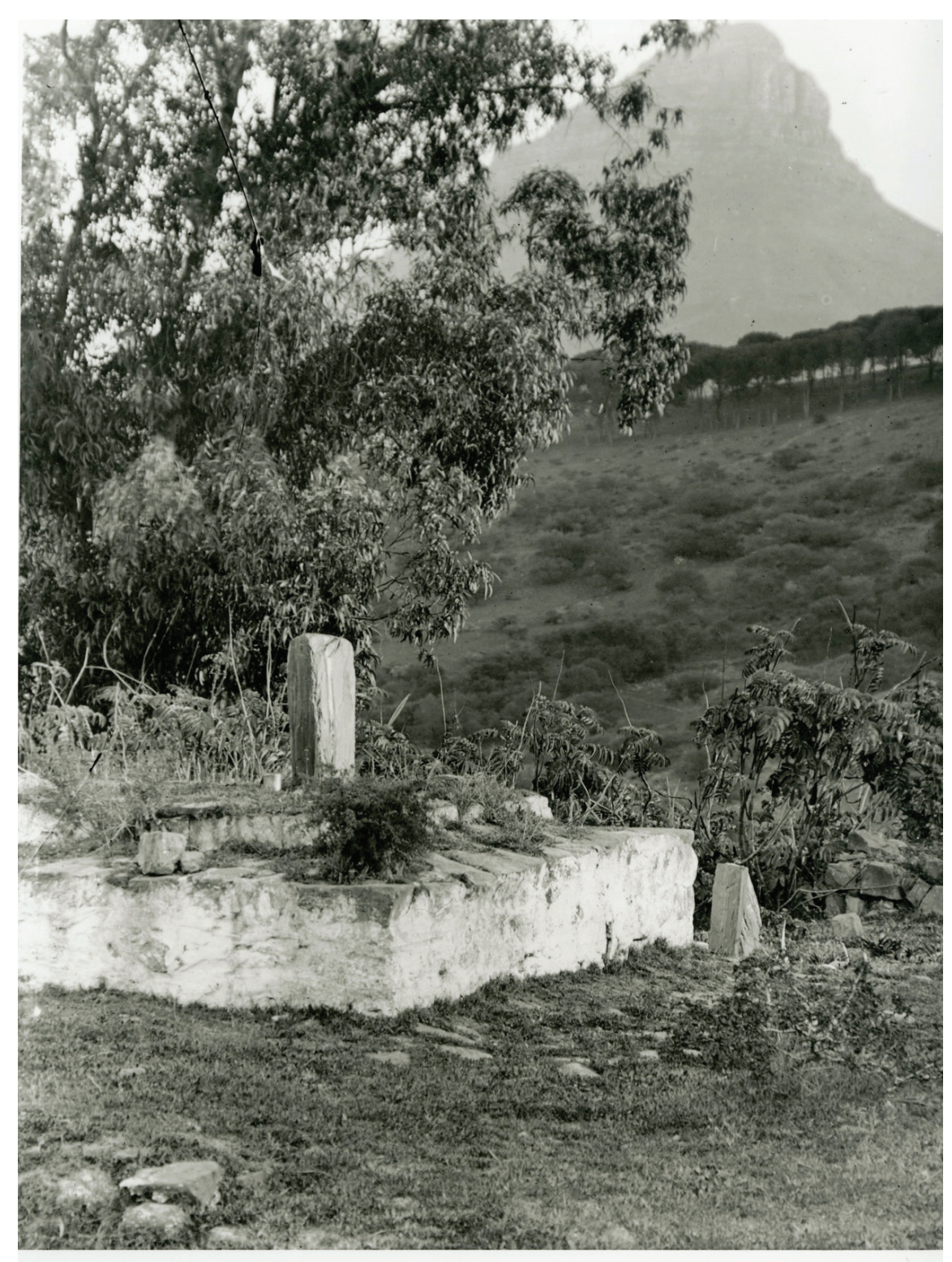

Fig.4 Noriman's grave as photographed by Arthur Elliott (1870-1938), c. 1910. Western Cape Provincial Archives and Records Service (KAB), CA 3927. Permission for reproduction gratefully acknowledged. 
Such accounts lean heavily on newspaper reports from the first half of the twentieth century. As K.M. Jeffries reported of a visit to the Bo Kaap in the mid-1930s, where she found the grave of the man "known affectionately among children and grown-ups as "Oupa Skapie":

It is said that he took as his home a solitary hut on Signal Hill, where he lived for many years. He was a religious man and spent most of his time in prayer and meditation. As far as can be gathered he was not a man of learning, but rather a simple and lovable character, who loved to gather round him all the children of the town, irrespective of colour or creed, for all children were alike children to Oupa Skapie. Then he would open the shabby knapsack he always carried, and produce a store of delicious sweetmeats that seemed inexhaustible to the youngsters. In fact, the knapsack had the reputation of being imbued with magic qualities, nor could anyone discover where the old man obtained the ingredients for the savoury concoctions which he made in the lonely hut on the hill. While he never worked, he seemed to lack for nothing in the way of sustenance, and this fact was largely responsible for the legends that grew up around his name, and led to his being revered as a saint who would never fail to give to those in need.

It became customary to visit the cemetery after his death, for the purpose of asking a blessing before setting out on a journey. A little earth from the tomb, it was thought, would ensure a safe return, since Oupa Skapie would never allow any of his beloved soil to remain far from its proper place. Other requests were also made at his grave. Women wanting a son, men who longed for success, mothers whose children were deformed or unfortunate, girls whose sweethearts were unfaithful - all appealed to the kindly mediation of Oupa Skapie and it is said that he has never been known to fail. One of the most remarkable cases is that of a man who was arrested for a serious crime. All the evidence pointed against him, and it seemed certain that he would be convicted. The night before the trial, however, after the man had been in gaol for three months, the mother decided to spend the night in prayer at the tomb of the saint. Exhausted with her vigil, she at length fell asleep, and dreamt that a tall figure in a green robe and a white turban came up to her, and assured her that all would be well. When she reached her home the following morning, she found that the real criminal had confessed his guilt, and that her son had been set at liberty. ${ }^{55}$

55. K.M. Jeffries, "The Malay Tombs of the Holy Circle,” The Cape Naturalist 1, no. 2 (1935): 42-43. 

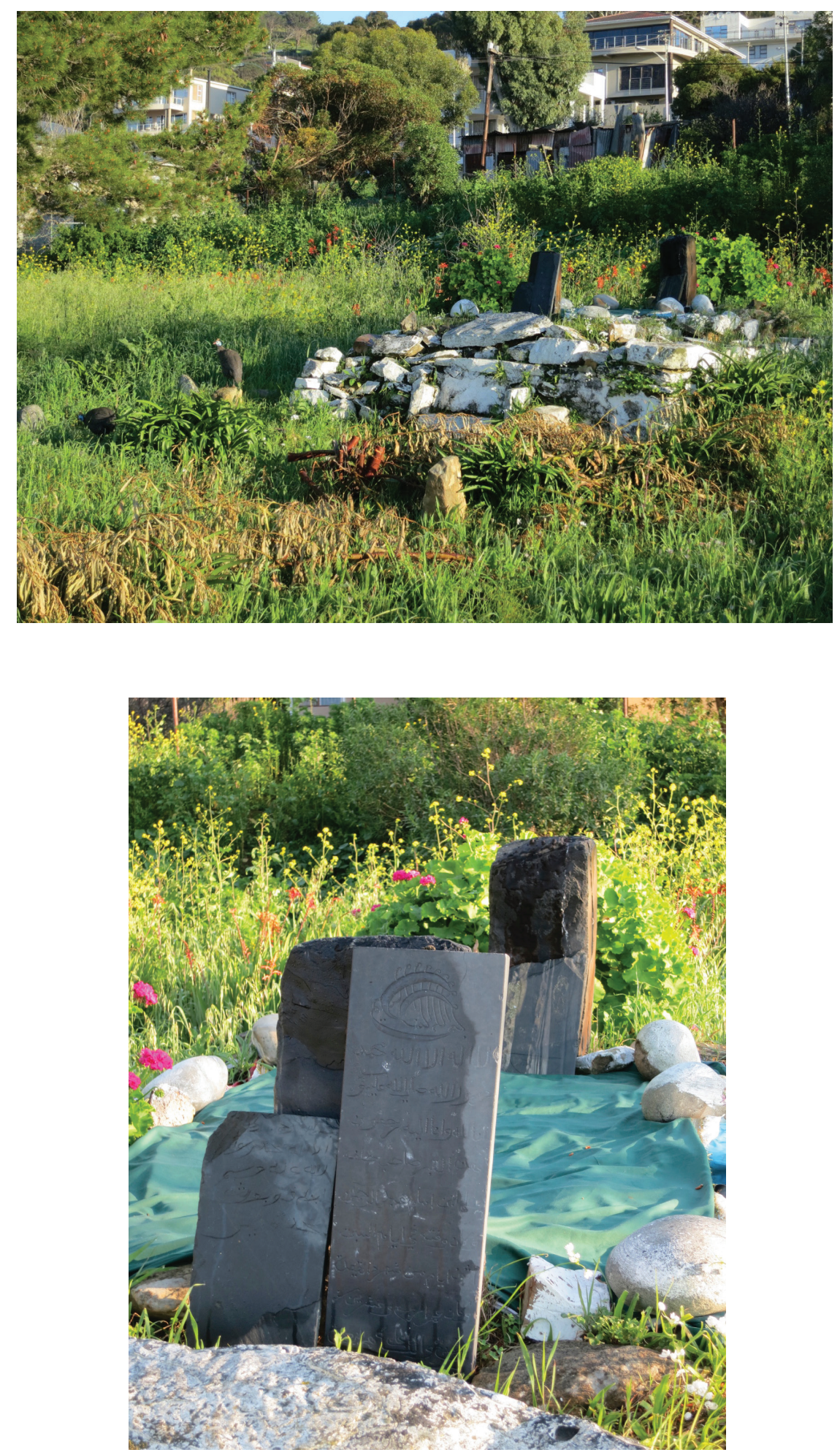

Fig.5 Noriman's grave as photographed by the author. September 2012. 


\section{Conclusion}

Today the specific powers of Oupa Skapie seem somewhat diminished in Cape Town, where there is less evidence of constant visitation to his grave, and far more attention placed in guidebooks on the orthodoxy of Tuan Guru and Alawi. Whereas the tombs of the latter two men were rebuilt in the 1970s, with one gaining a dome and the other even taking the shape of an unfinished pyramid, that of Noriman has been comparatively neglected. Further, the documents produced by the Cape Mazaar Society say little of his alleged healing powers even if they still mark him as one of the three "lords" (Tuan) of Signal Hill. The prayer banners remain, to be sure, but the plain headstone is bedecked by the Robben Island slates of several other figures, rendered in a script that Noriman seems not to have used. Was he a Bugis adventurer drawn to Cirebon in the 1770s, perhaps upsetting a local dynasty or the Dutch garrison? Did he eagerly offer magical projection to runaways in Cape Town in the 1780s? Or was he telling the truth during his interogation when he said that he knew nothing of the (now lost) lead amulet? Much depends, it seems, on determining the root causes of his family's sentencing to Cape Town, information that may yet be found in Jakarta, with its enormous VOC archive. Still, this may only show that the Dutch never knew just who they had in their clutches. From priest, to wayfarer, to calabash-wearing necromancer, Noriman remains elusive. 